\title{
PENGARUH METODE BERERITA TERHADAP KEMAMPUAN KOSAKATA ANAK USIA 5-6 TAHUN DI TK DARUSSALAM KUALU NENAS
}

\author{
Rika Andriyani ${ }^{1}$, Nurmalina ${ }^{2}$ \\ Program Studi Pendidikan Guru Pendidikan Anak Usia Dini, Universitas \\ Pahlawan Tuanku Tambusai \\ Email : rikaandriyani@gmail.com, nurmalina1812@yahoo.com
}

\begin{abstract}
Abstrak
Berdasarkan hasil pengamatan di TK Darussalam Kualu Nenas terhadap kemampuan kosakata anak belum berkembang dengan optimal. Sehingga perlu dilakukan penerapan kegiatan metode bercerita. Masalah dalam penelitian ini adalah kosakata yang dimiliki oleh anak rendah, ditandai ketika anak belum mampu menjawab pertanyaan yang diajukan. Penelitian ini bertujuan untuk mengetahui pengaruh metode bercerita terhadap kemampuan kosakata anak usia 5-6 tahun di TK Darussalam Kualu Nenas. Sampel penelitian berjumlah 15 anak. penelitian ini menggunakan teknik sampling jenuh. Teknik pengumpulan data yang digunakan adalah observasi dan dokumentasi. Teknik analisa data menggunakan statistik dengan uji t-test dengan program SPSS 16,0. Pengujian hipotesis dilakukan dengan menggunakan uji-t dengan teknik independent T-test, diperoleh $t_{h i} t_{u n g}$ sebesar 0,000 pada taraf signifikansi $a<0,005$. Dengan demikian $\mathrm{H}_{0}$ ditolak dan $\mathrm{H}_{\mathrm{a}}$ diterima karena $0,000<0,05$. Hal ini membuktikan bahwa metode bercerita berpengaruh terhadap kemampuan koskata pada anak usia 5-6 tahun di TK Darussalam Kualu Nenas.
\end{abstract}

Kata kunci: kemampuan kosakata, metode bercerita

\section{PENDAHULUAN}

Anak usia dini adalah anak yangcberada pada rentang usia 0-8 tahun. Padacmasa usia ini anak mengalami pertumbuhan yang sangat pesat, masa ini juga disebut masa keemasan (golden age) (Sujiono, 2009: 6). Ketika anak berada pada usia dini harus diberi stimulus dan pendidikan yang baik sehingga dapat merangsang perkembangan dan pertumbuhan anak secara optimal.

Berdasarkan Peraturan Menteri Pendidikan dan Kebudayaan Republik Indonesia Nomor 146 Tahun 2014 bahwa :

"Pendidikan anak usia dini (PAUD) merupakan pendidikan yang paling fundamental karena perkembangan anak di masa selanjutnnya akan sangat ditentukan oleh berbagai stimulasi bermakna sejak usia dini. Awal kehidupan anak merupakan masa yang paling tepat dalam memberikan dorongan atau upaya pengembangan agar anak dapat berkembang secara optimal". 
Pendidikan untuk anak usia dini memanglah sangat penting untuk merangsang pertumbuhan dan perkembangan anak. Pada masa golden age atau masa keemasannya, anak dapat diberikan dorongan dan upaya- upaya stimulasi sesuai tahapan perkembangan anak sehingga anak dapat berkembang secara optimal dan dapat terus berkembang pada masa selanjutnya Berdasarkan peraturan menteri pendidikan dan kebudayaan Republik Indonesia Nomor 137 tahun 2014 pasal 1 ayat 2 yaitu : Standar tingkat pencapaian perkembangan anak usia dini selanjutnnya disebut STPPA adalah kriteria tentang kemampuan yang dicapai anak pada seluruh aspek perkembangan dan pertumbuhan, mencakup aspek nilai agama dan moral, fisik-motorik, kognitif, bahasa, sosialemosional, serta seni.

Ada 6 (enam) aspek perkembangan anak yang sangat penting dikembangkan sejak usia dini, salah satunya adalah aspek bahasa. Bahasa merupakan suatu alat untuk menyampaikan ide/gagasanya kepada orang lain. Selain itu, penggunaan bahasa memanglah sangat penting untuk kehidupan sehari-hari. Dengan bahasa seseorang dapat berkomunikasi dan membentuk interaksi sosial.

Anak usia dini adalah individu yang sedang mengalami proses pertumbuhan dan perkembangan yang sangat pesat, bahkan dikatakan sebagai lompatan perkembangan. Anak usia dini memiliki rentang usia yang sangat berharga dibanding usia-usia selanjutnya karena perkembangan kecerdasannya sangat luar biasa. Usia tersebut merupakan fase kehidupan yang unik, dan berada pada masa proses perubahan berupa pertumbuhan, perkembangan, pematangan dan penyempurnaan, baik pada aspek jasmani maupun rohaninya yang berlangsung seumur hidup, bertahap dan berkesinambungan (Mulyasa, 2012: 16).

Anak belajar bahasa untuk pertama kalinya adalah sejak lahir. Bayi yang baru lahir hanya bisa menangis untuk mengungkapkan sesuatu kepada orang dewasa. Melalui tangisan itulah bayi mengungkapkan bahasanya yaitu bahasa bayi. Misanya ketika bayi lapar, ngompol, ataupun merasa tidak nyaman ia akan menangis sebagai bahasanya.

Berdasarkan pada rumusan masalah penelitian di atas, maka tujuan penelitian adalah untuk mengetahui pengaruh metode bercerita terhadap kemampuan kosakata pada anak usia 5-6 tahun di TK Darussalam Kualu Nenas.

Metode merupakan cara yang dalam fungsinya merupakan alat untuk mencapai tujuan kegiatan. Oleh karena itu, dalam memilih suatu metode yang akan dipergunakan dalam program kegiatan anak di taman kanak- kanak harus mempunyai alasan yang kuat dan faktor-faktor yang mendukung pemilihan metode tersebut.

Menurut Moeslichatoen (2004:7) metode merupakan bagian dari strategi kegiatan. Pendapat lain juga dikatan oleh Fadillah (dalam Rodiyah, 2013:9) bahwa metode adalah suatu cara kerja yang sistematis untuk memudahkan pelaksanaan kegiatan dalam mencapai suatu tujuan. Sedangkan metode pembelajaran adalah suatu cara atau system yang digunakan dalam pembelajaran yang bertujuan agar anak didik dapat mengetahui, memahami, 
mempergunakan dan menguasai bahan pelajaran tertentu.

Dalam pendidikan pemilihan metode yang sesuai sangat diperlukan, sebab dapat berpengaruh dalam mencapai keberhasilan pembelajaran. Ada beberapa metode pembelajaran yang dapat diterapkan pada taman kanak- kanak salah satunya adalah metode bercerita. Cerita adalah suatu seni dalam menyampaikan ilmu, pesan, nasihat, baik lisan maupun tulisan kepada orang lain yang sebagian besar bahannya berdasarkan fakta.

Menurut Cendekia (dalam Muyassaroh, 2015:8) Metode bercerita adalah metode yang sangat baik dan disukai oleh jiwa manusia karena memiliki pengaruh yang menakjubkan untuk dapat menarik perhatian pendengar dan membuat seseorang bisa mengingat kejadian- kejadian dalam sebuah kisah dengan cepat. Pendapat lain dikemukakan oleh Moeslichatoen (2004:157) bahwa metode bercerita merupakan salah satu pemberian pengalaman belajar bagi anak TK dengan membawakan cerita kepada anak secara lisan.Cerita yang digunakan harus menarik, dan mengundang perhatian anak dan tidak terlepas dari tujuan pendidikan bagi anak TK.

\section{METODE}

Tempat penelitian ini dilaksanakan di TK Darussalam Kualu Nenas yang terletak di Jl. Sei. Putih Desa Kualu Nenas. Waktu penelitian ini dilaksanakan pada semester ganjil Tahun ajaran 2016/2017 pada anak usia 5-6 tahun di TK Darussalam Kualu Nenas.

Menurut Suharsimi Arikunto (2006: 130), populasi adalah keseluruhan subjek penelitian yang terdiri dari manusia dan benda sebagai sumber data yang memiliki karakteristik tertentu dalam penelitian. Berdasarkan pendapat di atas, populasi pada penilitian ini adalah seluruh anak yang berusia 5-6 tahun di TK Darussalam Kualu Nenas di kelompok B yang berjumlah 15 anak.

Menurut Sugiyono (2014:118), sampel adalah bagian dari jumlah dan karakteristik yang dimiliki oleh populasi. Adapun sampel penelitian ini adalah jumlah keseluruhan dari populasi, yaitu kelompok B di TK Darussalam Kualu Nenas yang berjumlah 15 anak.

Adapun teknik pengumpulan data yang digunakan dalam penelitian ini adalah sebagai berikut: observasi, dokumentasi. Analisis data pada penelitian ini digunakan untuk menganalisis hasil eksperimen atau untuk menghitung efektivitas treatment untuk melihat pengaruh metode bercerita terhadap kemampuan kosakata sebelum dan sesudah diberi perlakuan. Adapun dalam proses analisa data ini menggunakan rumus uji t atau $t$-test.

\section{HASIL DAN PEMBAHASAN}

Pembahasan hasil penelitian ini dilalakukan melalui hasil analisis perbandingan pada penelitian dengan jenis penelitian eksperimen terhadap variabel bebas yaitu metode bercerita $(X)$ dan variabel terikat yaitu kosakata anak(Y). Untuk melihat perubahan sebelum dan setelah dilakukan perlakuan (treatment) terhadap sampel. Setelah melakukan hasil perbedaan nilai sebelum (pretest) dan setelah (posttest) dari perlakuan, langkah selanjutnya yaitu melihat kemampuan kosakata anak dengan perlakuan yang telah diberikan kepada anak. 
Metode bercerita merupakan salah satu pemberian pengalaman belajar dengan cerita. Melalui metode bercerita anak mendapat pengalaman serta pengetahuan yang akan disampaikan melalui cerita secara lisan. Selain itu metode bercerita dapat membantu anak dalam mengembangkan dan melatih kemampuan bahasa yang anak miliki.

Metode bercerita dapat berpengaruh terhadap kemampuan kosakata anak. Dengan cerita yang dikemas dan disajikan secara menarik anak akan memiliki ketertarikan terhadap kelanjutan cerita yang diberikan. Sehingga akan ada feedback atau timbal balik antara pesan yang telah disampaikan oleh guru dalam bentuk cerita dengan apa yang diterima oleh anak.

Metode bercerita disampaikan melalui cerita yang menarik dengan bantuan media pembelajaran. Cerita yang disampaikan harus mengandung pesan, nasihat, dan informasi yang dapat ditangkap oleh anak sehingga dapat memahami cerita serta meneladani hal- hal baik yang disampaikan. Melalui metode bercerita anak dapat mengembangkan kemampuan bahasannya, anak dapat menjawab pertanyaan yang diberikan oleh gurunya sehingga berpengaruh terhadap kemampuan kosakata anak.

Berdasarkan hasil analisis deskripsi kemampuan kosakata anak usia 5-6 tahun di TK Darussalam Kualu Nenas, dilihat pada hasil pretest diperoleh jumlah nilai 171 dengan rata-rata $11,4 \%$. Skor akhir tertinggi terdapat pada indikator "anak mampu menyebutkan warna dengan tepat" dengan jumlah skor 30, indikator kemampuan ini mendapat skor tertinggi karena hampir semua anak mampu menyebutkan warna dengan benar. Kemudian skor terendah terdapat pada indikator "anak mampu menyebutkan kelompok gambar yang memiliki bunyi yang sama" sesuai dengan jumlah skor 24 . Indikator ini mendapat nilai terendah dikarenakan anak belum mampu menyebutkan kelompok gambar yang memiliki bunyi yang sama dengan benar.

Pada hasil posttest atau setelah diberi perlakuan diperoleh nilai 255 dengan rata-rata $17 \%$. skor akhir tertinggi terdapat pada indikator kesatu dan kelima "menyebutkan kata benda nama anggota tubuh dan mengeksperesikan rasa/emosi" dengan jumlah skor 45 , indikator kemampuan ini mendapat skor tertinggi karena indikator ini diberi perlakuan. Kemudian skor terendah terdapat pada indikator keempat "menyebutkan kelompok gambar yang memiliki bunyi yang sama" dengan jumlah skor 40. Indikator ini menjadi indikator terendah sebelum diberi perlakuan .

Berdasarkan analisis pengolahan data dan hasil persentase di atas dapat di jelaskan hasil pretest anak usia 5-6 tahun di TK Darussalam Kualu Nenas diperoleh jumlah nilai 171 dengan rata-rata 11,4,. Jika dilihat secara kategori perorangan sebelum diberi perlakuan maka kategori BSB sebanyak 0 orang anak dengan presentase $0 \%$, anak yang pada kategori BSH sebanyak 2 orang anak dengan presentase $13 \%$, anak yang pada kategori MB sebanyak 10 orang anak dengan persentase $67 \%$, anak yang pada kategori BB sebanyak 3 orang anak dengan presentase $20 \%$. Begitu pentingnya kemampuan kosakata bagi anak, maka anak harus distimulasi agar kosakata anak dapar berkembang sesuai usianya. 
Melatih kemampuan kosakata anak dapat dilakukan dengan bantuan orang dewasa dan teman-temannya dengan kegiatan ataupun metode. Metode bercerita memungkinkan anak untuk berlatih kemampuan kosakata nya, maka tidak disadari kemampuan kosakata anak akan meningkat. Penelitian yang relevan dengan penelitian ini adalah penelitian yang dilakukan oleh Annisa Rohmatul Muyassaroh (2015) yang berjudul "Pengaruh Metode Bercerita Terhadap Kemamapuan Kosakata Dasar Anak Usia 4-5 tahun di RA Muslimat Banyumas" yang terbukti dapat mengembangkan dan meningkatkan kemampuan kosata kata anak usia 5-6 tahun dalam berkomunikasi dan menyampaikan suatu ide. Sehingga metode bercerita dapat berpengaruh terhadap kemampuan kosakata anak. Dengan cerita yang dikemas dan disajikan secara menarik anak akan memiliki ketertarikan terhadap kelanjutan cerita yang diberikan. Sehingga akan ada feedback atau timbal balik antara pesan yang telah disampaikan oleh guru dalam bentuk cerita dengan apa yang diterima oleh anak dalam mengembangkan kemampuan kosakata anak usia 5-6 tahun di TK Darussalam Kualu Nenas.

Penelitian eksperiman ini dilakukan untuk mengetahui adanya pengaruh signifikan sebelum dan setelah diberikan perlakuan metode bercerita. Uji signifikan perbedaan ini dengan $\mathrm{t}$ statistik diperoleh $\mathrm{t}_{\text {hitung }}=13,234$ dengan Sig $=$ 0,0000 , karena nilai sig $<0,05$ berarti signifikan. Jadi ada perbedaan perubahan kemampuan kosakata anak didik yang signifikan antara sebelum dan sesudah metode bercerita, dimana setelah perlakuan mempunyai perubahan lebih besar dibandingkan sebelum perlakuan. Hal ini adanya pengaruh kemampuan kosakata dengan metode bercerita.

Berdasarkan uraian di atas, dapat disimpulkan bahwa metode bercerita berpengaruh terhadap kemampuan kosakata anak usia 5-6 tahun di TK Darussalam Kualu Nenas.

\section{SIMPULAN}

Berdasarkan hasil penelitian yng dilakukan di TK Darussalam Kualu Nenas tentang Pengaruh Metode Bercerita Terhadap Kemampuan Kosakata Anak, maka peneliti menarik kesimpulan sebagai berikut:

Kemampuan Kosakata anak usia 5-6 tahun di TK Darussalam Kualu Nenas pada kelompok B sebelum di beri perlakuan berada pada kategori kurang, artinya kemampuan kosakata anak sebelum diberikan perlakuan kurang dan belum sesuai dengan yang diharapkan.

Kemampuan kosakata anak 5-6 tahun di TK Darussalam Kualu Nenas pada kelompok $B$ setelah diberikan perlakuan berada pada kategori baik, artinya dengan diberikannya perlakuan berupa metode bercerita, kemampuan kosakata anak menjadi meningkat dari kategori kurang menjadi kategori baik

Terdapat pengaruh yang signifikan metode bercerita terhadap kemampuan kosakata anak usia 5-6 tahun di TK Darussalam Kualu Nenas, dimana dapat diketahui ada perbedaan berupa pengingkatan kemampuan kosakata anak didik sebelum dan sesudah pelaksanaan dengan memberikan metode bercerita. 
Implikasi hasil penelitian merupakan dampak atau akibat yang ditimbulkan dari pelaksanaan penelitian. Akibat atau dampak hasil penelitian dapat diterima oleh peneliti maupun subjek penelitian. Berdasarkan hasil penelitian yang ditemukan dapat diketahui bahwa metode bercerita pada anak usia 5-6 tahun di TK Darussalam Kualu Nenas secara keseluruhan sangat efektif untuk meningkatkan kemampuan kosakata peserta didik.

Hal ini dikarenakan tujuan dalam kegiatan bercerita anak dibimbing mengembangkan kemampuan untuk mendengarkan cerita guru yang bertujuan untuk memberikan informasi atau menanamkan nilai-nilai sosial, moral, dan keagamaan serta pemberian informasi tentang fisik dan lingkungan sosial. Metode bercerita juga memberikan manfaat bagi peserta didik yaitu dengan bercerita dapat melatih daya serap atau daya tangkap anak usia dini, artinya anak usia dini dapat dirangsang, untuk mampu memahami isi atau ide-ide pokok dalam cerita secara keseluruhan serta melatih daya kensentrasi anak usia dini, untuk memusatkan perhatiannya kepada keseluruhan cerita, karena dengan pemusatan perhatian tersebut anak dapat melatih hubungan bagian-bagian cerita sekaligus menangkap ide pokok dalam cerita. Maka dapat disimpulkan bahwa metode bercerita dapat dijadikan sebagai salah satu alternatif untuk mengoptimalkan kemampuan kosakata anak didik. Berdasarkan kesimpulan dan implikasi di atas, maka saran peneliti yang berhubungan dengan penelitian ini adalah sebagai berikut:

\section{Bagi Pihak Penyelenggara Taman Kanak- kanak}

Berdasarkan dari hasil penelitian (posttest) yang menyatakan tingkat kemampuan kosakata anak di TK Darussalam Kualu Nenas berada pada kategori sedang, karena tidak semua anak memiliki kemampuan kosakata pada kategori tinggi. Maka pihak penyelenggara Taman Kanak-kanak atau sekolah memiliki kewajiban untuk meningkatkan kemampuan kosakata nak anak didiknya. Salah satu caranya yaitu menyediakan fasilitas berupa media- media atau alat pendukung belajar yang menarik dan mengesankan bagi anak, salah satunya yaitu menggunakan metode bercerita yang digunakan peneliti atau metode lainnya.

Bagi Pendidik

Berdasarkan dari hasil penelitian (posttest) yang menyatakan tingkat kemampuan kosakata anak di TK Darussalam Kualu Nenas berada pada kategori sedang, tidak semua anak memiliki kemampuan kosakata pada kategori tinggi. Maka pendidik memiliki kewajiban untuk meningkatkan kemampuan kosakata anak didiknya. Sebaiknya metode bercerita ini diteruskan sesuai dengan kebutuhan dan dikembangkan sebagai sarana untuk meningkatkan kemampuan kosakata anak usia dini sehingga anak lebih termotivasi dalam belajar.

Bagi peneliti dan peneliti selanjutnya Dapat dijadikan acuan untuk meneliti terkait kemampuan kosakata anak dan harapan peneliti agar memilih media yang lebih menarik lagi dan sesuai dengan karakter anak usia dini dan waktu penelitian yang digunakan lebih lama sehingga penelitian diharapkan lebih efektif. Studi pendahuluan yang lebih mendalam agar penelitian lebih mengungkapkan dan menemukan fenomena baru terkait dengan meningkatkan 
kemampuan koskakata anak usia dini.

\section{DAFTAR PUSTAKA}

Arikunto, Suharsimi. 2006. Prosedur Penelitian Suatu Pendekatan Praktik. Jakarta: PT Rineka Cipta.

Bimo. (2010). Makalah Ringkas. [Online]. Tersedia dalam: https://kakbimo.wordpress.com/makalah- ringkas/ [diakses 25 Desember 2017].

Dhieni, Nurbiana dkk. 2007. Metode Pengembangan Bahasa. Jakarta: Universitas Terbuka.

Fauziddin, Mohammad. 2014. Pembelajaran Paud. Bandung: PT Remaja Rosdakarya.

Gusmalinda, 2016. Pengaruh Media Gambar Diam Terhadap Kemampuan Berbicara Anak Uisa 5-6 Tahun Di Paud Kemuning Kecamatan Tenayan Raya Pekanbaru. Universitas Riau: Pekanbaru

Hartono. (2012). Statistik untuk Penelitian. Yogyakarta: Pustaka Pelajar. https://dongengceritarakyat.com/wp- content/uploads/2017/02/dongengfabel- kuda-dan-kancil.jpg [Diakses 11 Juli 2018] https://media.neliti.com/media/publication s/Article. Html [Diakses 30 Desember 2017]

Kamus Besar Bahasa Indonesia, 2001. Departemen Pendidikan Nasional Menteri Pendidikan dan Kebudayaan Republik Indonesia. 2014. Peraturan Menteri Pendidikan dan Kebudayaan Republik Indonesia Nomor 137 Tahun 2014 Tentang Standar Nasional Pendidikan Anak Usia Dini. Menteri Pendidikan dan Kebudayaan Republik Indonesia : Jakarta.

Moeslichatoen. (2004). Metode Pengajaran di Taman Kanak-Kanak. Jakarta: Rineka Cipta.

Mulyasa. (2012). Manajemen Paud. Bandung:PT. Remaja Rosdakarya

Muyassaroh, Rohmatul Annisa, Jurnal. Pengaruh Metode Bercerita Terhadap Kemampuan Kosakatadasar Anak Usia 45 Tahun Di RA Muslimat Banyumas Kabupaten Pringsewu. [Diakses] Tersedia Dalam Http://Ejournal

Naibaho, Santha. (2017). Pengaruh Kegiatan Kolase Montase Terhadap Kemampuan Motorik Halus Anak Usia 56 Tahun di TK Tunas Melati Kandis, Kabupaten Siak. Univrsitas Riau: Pekanbaru

Rodiyah, Asri. (2013). Penggunaan Metode Bercerita Untuk Meningkatkan Kosakata Anak Usia 3-4 Tahun Pada Play Group Tunas Bangsa Mojokerto. [Online] Tersedia dalam http://webcache.googleusercontent.com/se arch? q=cache:i AyZ qq6jj nEJ :j urnalmahasi swa.unesa.ac.id/article/1437/19/article. $p d f+\& c d=5 \& h l=i d \& c t=c l n k \& g l=i d$ [Diakses 05 Januari 2018]

Sardi, N dkk. (2012). Pengaruh Pembelajaran dengan Teknik Bercerita DongengTerhadap Kemampuan Berbahasa dan Motovasi Anak Kelompok B TK Kunti II Dalung. [Online] Tersedia dalam

Sugiyono. (2012). Memahami Penelitian Kualitatif. Bandung: Angkasa.

Sujiono, Yuliani Nurani. (2009). Konsep Dasar Pendidikan Anak Usia Dini. Jakarta: PT Indeks.

Sukardi. (2012). Metodologi Penelitian Pendidikan. Jakarta: PT Bumi Aksara.

Sunariyanto. (2015). Upaya Meningkatkan Kemampuan Berbicara Anak Usia 5-6 tahun dengan Media Poster Di TK ABA Yogyakarta. [Online] Tersedia dalamhttp://webcache.googleusercontent.c om/search?q=cache:1c9ko2HMVbUJjournal.student.uny.ac.id/ojs/index.ph p/pgpau d/article/viewFile/320/292+\&cd=10\&hl=i d\&ct=clnk\&gl=id [Diakses 05 Januari 2018]

Tarigan, Henry Guntur. (2011). Menyimak Sebagai Keterampilan Bahasa. Bandung: Angkasa. 
Yus, Anita. (2011). Model Pendidikan Anak Usia Dini: Kencana 